\title{
Genes associated with histopathologic features of triple negative breast tumors predict molecular subtypes
}

\section{Purrington, Kristen S.}

2016-05

Purrington, K S , Visscher , D W , Wang , C , Yannoukakos , D , Hamann , U , Nevanlinna , H, Cox , A, Giles , G G , Eckel-Passow , J E , Lakis , S , Kotoula , V , Fountzilas , G , Kabisch, M , Ruediger , T , Heikkila , P , Blomqvist , C, Cross , S S , Southey , M C , Olson , J E , Gilbert , J, Deming-Halverson , S , Kosma , V-M , Clarke , C , Scott , R , Jones , J L , Zheng , W, Mannermaa , A, Eccles , D M , Vachon, C M , Couch , F J \& Jane Carpenter ABCTC Investigators 2016, ' Genes associated with histopathologic features of triple negative breast tumors predict molecular subtypes ' , Breast Cancer Research and Treatment, vol. 157 , no. 1 , pp. 117-131 . https://doi.org/10.1007/s10549-016-3775-2

http://hdl.handle.net/10138/224013

https://doi.org/10.1007/s10549-016-3775-2

publishedVersion

Downloaded from Helda, University of Helsinki institutional repository.

This is an electronic reprint of the original article.

This reprint may differ from the original in pagination and typographic detail.

Please cite the original version. 


\title{
Genes associated with histopathologic features of triple negative breast tumors predict molecular subtypes
}

\author{
Kristen S. Purrington ${ }^{1,2} \cdot$ Daniel W. Visscher ${ }^{3} \cdot$ Chen Wang $^{2} \cdot$ Drakoulis Yannoukakos $^{4} \cdot$

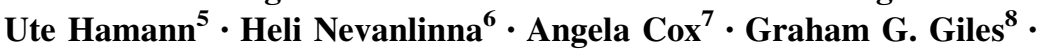 \\ Jeanette E. Eckel-Passow ${ }^{2}$ - Sotiris Lakis ${ }^{9}$ - Vassiliki Kotoula ${ }^{9}$ George Fountzilas ${ }^{9}$ \\ Maria Kabisch $^{5}$ - Thomas Rüdiger $^{10} \cdot$ Päivi Heikkilä ${ }^{11}$ - Carl Blomqvist ${ }^{12}$. \\ Simon S. Cross ${ }^{13} \cdot$ Melissa C. Southey ${ }^{14} \cdot$ Janet E. Olson $^{2} \cdot$ Judy Gilbert ${ }^{3}$ • \\ Sandra Deming-Halverson ${ }^{15}$ • Veli-Matti Kosma ${ }^{16,17}$ - Christine Clarke ${ }^{18}$. \\ Rodney $\operatorname{Scott}^{19}$ - J. Louise Jones ${ }^{20}$ - Wei Zheng ${ }^{15}$ - Arto Mannermaa ${ }^{16,17}$. \\ Jane Carpenter for ABCTC Investigators ${ }^{21}$ - Diana M. Eccles $^{22}$ - Celine M. Vachon ${ }^{2}$. \\ Fergus J. Couch ${ }^{2,3}$
}

Received: 17 October 2015/Accepted: 30 March 2016/Published online: 15 April 2016

(C) Springer Science+Business Media New York 2016

\begin{abstract}
Distinct subtypes of triple negative (TN) breast cancer have been identified by tumor expression profiling. However, little is known about the relationship between histopathologic features of $\mathrm{TN}$ tumors, which reflect aspects of both tumor behavior and tumor microenvironment, and molecular TN subtypes. The histopathologic features of TN tumors were assessed by central review and
\end{abstract}

Electronic supplementary material The online version of this article (doi:10.1007/s10549-016-3775-2) contains supplementary material, which is available to authorized users.

Fergus J. Couch

couch.fergus@mayo.edu

1 Department of Oncology, Wayne State University School of Medicine and Karmanos Cancer Institute, Detroit, USA

2 Department of Health Sciences Research, Mayo Clinic, Stabile 2-42, Mayo Clinic, 200 First Street SW, Rochester, MN 55905, USA

3 Department of Laboratory Medicine and Pathology, Mayo Clinic, Rochester, USA

4 Molecular Diagnostics Laboratory INRASTES, National Centre for Scientific Research "Demokritos", Athens, Greece

5 Molecular Genetics of Breast Cancer, German Cancer Research Center (DKFZ), Heidelberg, Germany

6 Department of Obstetrics and Gynecology, University of Helsinki and Helsinki University Central Hospital, Helsinki, Finland

7 Department of Oncology, University of Sheffield, Sheffield, UK

8 Cancer Epidemiology Centre, The Cancer Council Victoria, Melbourne, Australia
593 TN tumors were subjected to whole genome expression profiling using the Illumina Whole Genome DASL array. TN molecular subtypes were defined based on gene expression data associated with histopathologic features of TN tumors. Gene expression analysis yielded signatures for four TN subtypes (basal-like, androgen receptor positive, immune, and stromal) consistent with previous studies. Expression analysis also identified genes significantly associated with the 12 histological features of TN tumors. Development of signatures using these markers of

9 Laboratory of Molecular Oncology, Hellenic Foundation for Cancer Research, Aristotle University of Thessaloniki School of Medicine, Thessaloniki, Greece

10 Institute of Pathology, Städtisches Klinikum Karlsruhe, Karlsruhe, Germany

11 Department of Pathology, University of Helsinki and Helsinki University Central Hospital, Helsinki, Finland

12 Department of Oncology, University of Helsinki and Helsinki University Central Hospital, Helsinki, Finland

13 Department of Neuroscience, University of Sheffield, Sheffield, UK

14 Genetic Epidemiology Laboratory, Department of Pathology, The University of Melbourne, Melbourne, Australia

15 Division of Epidemiology, Department of Medicine, Vanderbilt Epidemiology Center, Vanderbilt-Ingram Cancer Center, Vanderbilt University School of Medicine, Nashville, USA

16 Imaging Center, Department of Clinical Pathology, Kuopio University Hospital, Kuopio, Finland 
histopathological features resulted in six distinct TN subtype signatures, including an additional basal-like and stromal signature. The additional basal-like subtype was distinguished by elevated expression of cell motility and glucose metabolism genes and reduced expression of immune signaling genes, whereas the additional stromal subtype was distinguished by elevated expression of immunomodulatory pathway genes. Histopathologic features that reflect heterogeneity in tumor architecture, cell structure, and tumor microenvironment are related to TN subtype. Accounting for histopathologic features in the development of gene expression signatures, six major subtypes of TN breast cancer were identified.

Keywords Gene expression - Pathology - Tumor biology $\cdot$ Germline mutation $\cdot$ Breast cancer

\section{Introduction}

Triple negative (TN) breast cancer is a distinct histopathological subtype of breast cancer that accounts for approximately $15 \%$ of all invasive breast cancers [1,2]. This disease subtype, defined by low or no expression of estrogen receptor (ER), progesterone receptor (PR), and human epidermal growth factor receptor-2 (HER2) is treated as a single group clinically. However, TN tumors have been shown to have significant biological heterogeneity that is not captured by clinical subtyping alone [3]. Intrinsic subtypes of breast tumors based on gene expression profiling have been defined using the PAM50 expression microarray. These include two luminal epithelial groups (A and B), a HER2 over-expressing group, a normal-like group, and a basal-like group that is largely TN $(80-85 \%)[4,5]$. Separately, six subtypes of TN breast cancer (referred to here as Lehmann subtypes) have been defined using combined gene expression microarray data from several studies. These subtypes were classified as

17 School of Medicine, Institute of Clinical Medicine, Pathology and Forensic Medicine, Biocenter Kuopio, Cancer Center of Eastern Finland, University of Eastern Finland, Kuopio, Finland

18 Centre for Cancer Research, University of Sydney at the Westmead Millennium Institute, Westmead, Australia

19 Division of Genetics, Hunter Area Pathology Service and University of Newcastle, Newcastle, Australia

20 Barts Cancer Research Institute, Queen Mary University of London, London, UK

21 University of Sydney at the Westmead Millennium Institute, Australian Breast Cancer Tissue Bank, Westmead, Australia

22 Faculty of Medicine and NIHR/CRUK Clinical Trials Unit, University of Southampton, Southampton, UK basal-like 1 (BL1), basal-like 2 (BL2), immunomodulatory (IM), mesenchymal (M), mesenchymal stem-like (MSL), and luminal androgen receptor (LAR) [6].

Independent analyses of microarray data for TN tumors, which had substantial overlap with the original TN study, further suggested that the TN subtypes are driven in part by differences in tumor microenvironment [7]. Specifically, four main gene expression clusters were found, representing a stromal gene signature, a luminal signature, an immune signature, and a basal epithelial signature. Consistent with this model, these gene signatures were not observed in cell lines or xenografted tumors. Thus, the TN subtypes may reflect genomic heterogeneity in tumor cells and/or expression changes resulting from microenvironmental influences. Importantly, these models may have implications for breast cancer treatment and outcome, because tumor microenvironment features, including lymphocytic infiltration and fibrosis, have been associated with breast cancer progression and prognosis [8-12]. Indeed, pathologic complete response rates after neoadjuvant chemotherapy may differ by Lehmann subtype [13], suggesting that TN subtypes may have distinct prognostic implications.

TN tumors exhibit high histologic grade and proliferation rates relative to other breast tumor subtypes [1, 14]. In addition, TN tumors have greater frequencies of several distinguishing histopathologic features including medullary and metaplastic features, pushing borders, fibrous proliferation, lymphocytic infiltrate within the tumor and in lobules adjacent to the tumor, elevated mitotic count, necrosis, and the presence of many syncytial clusters [15-17]. However, the relationship between these features and both TN expression signatures and TN subtypes is not well defined. In this study we identified molecular subtypes of TN tumors based on expression profiles and 11 histopathologic features of $\mathrm{TN}$ tumors from the triple negative breast cancer consortium in order to evaluate the relationship between gene expression patterns and key structural and microenvironment features of TN tumors.

\section{Methods}

\section{Study participants}

TNBCC cases $(n=704)$ from ten studies described in detail elsewhere, were included (Table S1) [18-20]. TN breast cancer cases were defined as individuals with ERnegative, PR-negative, and HER2-negative ( 0 or 1 by IHC) breast tumors. Criteria used for defining ER, PR, and HER2 status varied by study and have been previously described [18-20]. 


\section{Macrodissection, RNA extraction, and gene expression profiling}

Tumor samples were either whole 10 micron sections or $1 \mathrm{~mm}(\mathrm{~mm})$ cores from formalin-fixed paraffin-embedded tumor blocks (Table S1). Whole sections were macrodissected to select the tumor region on the slide, guided by a hematoxylin and eosin (H\&E)-stained slide from the same block, reviewed and marked by a single pathologist (D. Visscher). RNA was extracted from all tissue specimens using the Roche High Pure RNA Isolation Kit (Indianapolis, USA). Expression profiling was performed by the Mayo Clinic Medical Genome Facility Gene Expression Core (Rochester, MN, USA) using the Illumina Whole Genome cDNA-mediated annealing, selection, extension, and ligation (DASL) v4.0 assay. RNA samples were run on 12-sample chips in two batches (456 samples and 288 samples, respectively).

\section{Normalization, data reduction, and batch effect removal}

Raw intensity data were exported from the Illumina iScan software (Figs. S1, S2). Given the difference in median expression of per-sample median values between batches (Batch 1 median $=8.1$, Batch 2 median $=10.7$, Wilcoxon $p=1.1 \times 10^{-99}$ ), all subsequent quality control and normalization procedures were performed separately by batch. Median $R^{2}$ between 22 replicates was 0.91 (Batch 1 median $R^{2}=0.91$, Batch 2 median $R^{2}=0.99$ ).

After log-2 transformation and exclusion of all universal human reference samples (Batch $1 n=10$, Batch $2 n=6$ ), an iterative median quantile normalization (MQN) procedure using cyclic stress reduction separately by batch was performed. First, MQN was applied and a stress measurement was calculated for each sample, equivalent to the median absolute deviation after normalization [21]. The top $10 \%$ of samples with the highest stress was removed, and the MQN and stress calculation were repeated until only $30 \%$ of the original dataset-those with the least stress during repeated normalization remained. This leaststressed dataset was used as a reference for MQN of the full dataset and recalculated stress (Figs. S3, S4). Samples with stress $\geq 0.5$ were excluded (Batch $1 n=27$, Batch 2 $n=6$ ); for replicates, the sample with the highest stress was excluded (Batch $1 n=16$, Batch $2 n=10$ ). Probes with $p$-value of detection $>0.05$ were excluded (Batch 1 $n=713$, Batch $2 n=479$ ).

Expressions of ER (ESR1, Illumina probe ILMN 1678535), PR (PGR, Illumina probe ILMN_1811014), and HER2 (ERBB2, Illumina probe ILMN_2352131) were evaluated [22]. The expression values for each of the PAM50 genes, that can be used to define breast cancer subtypes [luminal A (LumA), luminal B (LumB), basal-like, HER2enriched (HER2), normal-like (NL)], were correlated with the gene expression centroids for each subtype, using centroid parameters from the "genefu" Bioconductor package (http:// www.bioconductor.org/). When multiple probes existed for a gene, the correlation between each probe and the corresponding PAM50 gene was included. Each sample was assigned a PAM50 subtype according to the best correlated subtype (Table S2). A total of 78 samples (Batch $1 n=51$, Batch $2 n=27$ ) were excluded where the standard deviation of ESR1 expression was $\geq 1.5$ from the mean (Fig. S5; Table S2). No further exclusions based on $P G R$ or ERBB2 expression were made (Figs. S6, S7).

Batch effects in the final dataset of 593 samples (Batch 1 $n=352$, Batch $2 n=241$ ) were corrected by standardization of probes (subtracting the mean expression value and dividing by standard deviation) by study. There was no evidence for batch effects after standardization by 12-sample chip, 96-well plate, study, or batch (Fig. S8), and all samples were combined into a single dataset for subsequent analyses. Lehmann subtypes were determined via hierarchical clustering using Ward's linkage as implemented in the "hclust" $\mathrm{R}$ package, using probes corresponding to 2119 out of the 2188 Lehmann centroid genes [6] for which normalized DASL data were available. When multiple probes were available for a gene, the most variable probe was chosen.

\section{Agnostic subtype derivation and functional annotation}

Hierarchical clustering including the 2158 most variable probes, defined by skewness and interquartile range (Table S3; Fig. S9), was performed using Ward's linkage as implemented in the "hclust" $\mathrm{R}$ package. Consensus clustering was used to determine the number of stable clusters (1000 iterations with average linkage). The optimal number of clusters, representing TN subtypes, was selected as the number at which no substantial increase in the area under the cumulative distribution function was observed. Functional annotation of TN subtypes was performed using gene set enrichment analysis (GSEA) as implemented in GSEA v2.1.0 software using default parameters [23, 24] and a normalized enrichment score $(\mathrm{NES}) \geq 1.5$. The single probe with the largest interquartile range was used for each gene. Genes within each subtype were tested for enrichment of $\mathrm{C} 2$ curated canonical pathways compared to all remaining subtypes using 1000 permutations. A gene signature for these pathways was developed using significance analysis of microarrays (SAM) as implemented in the "samr" $\mathrm{R}$ package (http:// cran.r-project.org/) with 100 permutations. Genes were evaluated for associations with each TN subtype relative to 
all TN tumors combined. Among genes significant at a false discovery rate of 0.1 using the Wilcoxon rank sum test, those up- and down-regulated by $>3$-fold standard deviations from the mean for each feature were selected (Table S4).

\section{Histopathologic features: review and subtype derivation}

H\&E slides were available for 310 of the $593 \mathrm{TN}$ tumors included in subtype analyses. Tumors were evaluated for 21 histopathological categories and for 11 histopathological features by a single pathologist (D. Visscher) (Tables S5, S6). Categories of certain tumor features were collapsed due to small numbers as follows: mitotic index $(1 / 2 ; 3)$, grade $(1 / 2 ; 3)$, trabecular pattern (present; absent), necrosis (present; absent), fibrosis $(0 / 1 ; 2 / 3)$, ductal carcinoma in situ (DCIS present; absent), lobulitis $(0 / 1 ; 2 ; 3)$. Lobular involution was evaluated as previously described $[25,26]$. Genes were evaluated for association with individual histopathologic features using SAM with 100 permutations. Among genes significant at a false discovery rate of 0.1 by the Wilcoxon rank sum test, up-regulated genes with a fold change $>1.5$ and down-regulated genes with fold change $<0.67$ were selected for each feature (Table S7). A gene signature for phenotype-driven subtypes was identified by SAM. Among genes significant at $10 \%$ FDR, those up- and down-regulated by $>3$-fold standard deviations from the mean for each feature were selected (Table S8). Lasso-based multinomial regression predicting TN subtype based on histopathologic features was performed with the "glmnet" package in R using cross validation. Per-gene linear regression models were performed using the "lm" function in $\mathrm{R}$ to evaluate the multivariate associations between age, histopathologic features, and each of 185 genes from the SAM-derived gene signature. Coefficients with $p<0.01$ were considered statistically significant.

\section{Germline mutation detection}

The methods for detecting mutations in 17 breast cancer predisposition genes (BRCA1, BRCA2, PALB2, BARD1, BRIP1, RAD51C, RAD51D, RAD50, NBN, MRE11A, XRCC2, ATM, CHEK2, TP53, PTEN, STK11, and CDH1) in germline DNA samples matched to these TN tumors has been described previously [27]. Briefly, germline DNA samples from TN patients were subjected to custom capture (eArray; Agilent, Santa Clara, CA, USA) for all coding sequences and intron/exon boundaries of coding exons for these genes. Products from each capture reaction were sequenced on a HiSeq 2000 (Illumina, San Diego, CA, USA). Pathogenic mutations were validated by Sanger sequencing. Mutation screening data were available for 156 TN tumors in this study.

\section{Results}

\section{Intrinsic subtype classification}

Whole genome expression profiling was analyzed for 593 TN tumors from the TNBCC with clinical ER-, PR-, and HER2-negative status. Initially, each sample was assigned an intrinsic breast tumor subtype using published PAM50 gene expression centroids, where $76.7 \%$ was identified as basal-like, $11.6 \%$ as normal-like, $9.1 \%$ as luminal, and $2.5 \%$ as HER2-enriched (Table S2). These findings were consistent with PAM50 distributions among TN tumors from clinical trials and publically available microarray data [7, 28]. We also assigned Lehmann subtypes (denoted with prefix "L-") using published Lehmann centroid genes in a hierarchical clustering analysis, where $13.2 \%$ was identified as L-BL1, $36.3 \%$ as L-BL2, $11.3 \%$ as L-LAR, $23.8 \%$ as L-IM, $10.1 \%$ as L-M, and $5.4 \%$ as L-MSL.

\section{Derivation of TN subtypes}

We first performed unsupervised hierarchical clustering to identify molecular subtypes of $\mathrm{TN}$ breast cancer. Using 2158 highly variable probes, the data were clustered into four groups using the Engelman-Hartigan test (Table 1; Fig. 1a), which was confirmed by analysis of sample classification robustness using consensus clustering (Fig. 1b, c). GSEA revealed a basal-like signature (BL) $(50.8 \%)$, a luminal signature (LAR) with overexpression of androgen receptor (AR) and AR transcriptional targets (10.6\%), an immune signature (IM) (16.9\%), and a stromal signature (STR) (21.7 \%) (Fig. 2). Tumors defined by PAM50 modeling as LumA, LumB, and HER2-enriched were assigned predominantly to the LAR subtype, while the PAM50 basal-like tumors were divided between the BL (61\%), IM (16\%), and STR (23\%) subtypes. NL tumors were evenly distributed across all four TN subtypes (Table 1). The LAR subtype was also associated with older age $($ mean $=62.1)$ compared to non-LAR subtypes $($ mean $=50.6) \quad\left(p=1.5 \times 10^{-8}\right) . \quad$ Enriched signaling pathways among these four subtypes were similar to those seen for comparable groups within the Lehmann classification scheme (Table S9). This is further confirmed by the overlap between agnostic subtypes and Lehmann subtype assignments (Table 1), where roughly $80 \%$ of the BL, LAR, and IM groups and $63 \%$ of the STR group were assigned to analogous Lehmann subtypes. The most notable departure in agreement is the presence of L-IM tumors in the BL and STR groups. When exploring the 
Table 1 Distribution of intrinsic subtypes and histopathologic features among four agnostic subtypes

\begin{tabular}{|c|c|c|c|c|c|c|c|}
\hline & $\begin{array}{l}\mathrm{BL} \\
n(\%) \\
N=301\end{array}$ & $\begin{array}{l}\text { LAR } \\
N(\%) \\
N=63\end{array}$ & $\begin{array}{l}\mathrm{IM} \\
N(\%) \\
N=100\end{array}$ & $\begin{array}{l}\text { STR } \\
n(\%) \\
N=129\end{array}$ & $\begin{array}{l}p \text {-value } \\
\text { four subtypes }\end{array}$ & $\begin{array}{l}p \text {-value } \\
\mathrm{B} \text { versus } \mathrm{NB}^{\mathrm{a}}\end{array}$ & $\begin{array}{l}p \text {-value } \\
\text { BL, IM, STR }\end{array}$ \\
\hline \multicolumn{8}{|l|}{ PAM50 subtype } \\
\hline Basal & $278(92)$ & $0(0)$ & $74(74)$ & $103(80)$ & & & \\
\hline HER2-enriched & $1(0.5)$ & $23(37)$ & $5(5)$ & $6(5)$ & & & \\
\hline Luminal A & $0(0)$ & $15(24)$ & $2(2)$ & $2(1)$ & & & \\
\hline Luminal B & $1(0.5)$ & $7(11)$ & $2(2)$ & $5(4)$ & & & \\
\hline Normal-like & $21(7)$ & $18(29)$ & $17(17)$ & $13(10)$ & $7.2 \times 10^{-61}$ & & \\
\hline \multicolumn{8}{|l|}{ Lehmann subtype } \\
\hline L-BL1 & $60(20)$ & $0(0)$ & $15(15)$ & $3(2)$ & & & \\
\hline L-BL2 & $186(62)$ & $3(5)$ & $3(3)$ & $23(18)$ & & & \\
\hline L-LAR & $2(0.7)$ & $52(83)$ & $5(5)$ & $8(6)$ & & & \\
\hline L-IM & 49 (16) & $5(8)$ & $74(74)$ & $13(10)$ & & & \\
\hline L-M & $3(1)$ & $1(2)$ & $3(3)$ & $53(41)$ & & & \\
\hline \multirow[t]{2}{*}{ L-MSL } & $1(0.3)$ & $2(3)$ & $0(0)$ & $29(22)$ & $2.5 \times 10^{-48}$ & & \\
\hline & $\begin{array}{l}\mathrm{BL} \\
n(\%) \\
N=161\end{array}$ & $\begin{array}{l}\text { LAR } \\
N(\%) \\
N=37\end{array}$ & $\begin{array}{l}\mathrm{IM} \\
N(\%) \\
N=55\end{array}$ & $\begin{array}{l}\text { STR } \\
n(\%) \\
N=58\end{array}$ & $\begin{array}{l}p \text {-value } \\
\text { four subtypes }\end{array}$ & $\begin{array}{l}p \text {-value } \\
\mathrm{B} \text { versus } \mathrm{NB}^{\mathrm{a}}\end{array}$ & $\begin{array}{l}p \text {-value } \\
\text { BL, IM, STR }\end{array}$ \\
\hline \multicolumn{8}{|l|}{ Mitotic index } \\
\hline 1 or 2 & $23(14)$ & $17(46)$ & $10(18)$ & $12(21)$ & & & \\
\hline 3 & $138(86)$ & $20(54)$ & $45(82)$ & $46(79)$ & $2.7 \times 10^{-4}$ & $6.3 \times 10^{-5}$ & 0.49 \\
\hline \multicolumn{8}{|l|}{ Grade } \\
\hline 1 or 2 & $13(8)$ & $10(27)$ & $4(7)$ & $9(16)$ & & & \\
\hline 3 & $148(92)$ & $27(73)$ & $51(93)$ & $49(84)$ & $6.0 \times 10^{-3}$ & $4.3 \times 10^{-3}$ & 0.21 \\
\hline \multicolumn{8}{|l|}{ Trabecular pattern } \\
\hline Absent & $88(55)$ & $31(84)$ & $38(69)$ & $39(67)$ & & & \\
\hline$\geq$ Present & $73(45)$ & $6(16)$ & $17(31)$ & $19(33)$ & $5.0 \times 10^{-3}$ & $9.2 \times 10^{-3}$ & 0.079 \\
\hline \multicolumn{8}{|l|}{ Growth pattern } \\
\hline Epicenter & $107(66)$ & $13(35)$ & $33(61)$ & $38(66)$ & & & \\
\hline Infiltrative & $45(28)$ & $18(49)$ & $19(35)$ & $18(31)$ & & & \\
\hline Multifocal & $9(6)$ & $6(16)$ & $2(4)$ & $2(3)$ & 0.011 & $4.9 \times 10^{-4}$ & 0.83 \\
\hline \multicolumn{8}{|l|}{ Necrosis } \\
\hline Absent & $52(32)$ & $25(68)$ & $36(65)$ & $29(50)$ & & & \\
\hline$\geq$ Present & $109(68)$ & $12(32)$ & $19(35)$ & $29(50)$ & $3.9 \times 10^{-6}$ & $7.5 \times 10^{-3}$ & $4.5 \times 10^{-5}$ \\
\hline \multicolumn{8}{|l|}{ Fibrosis } \\
\hline 0 or 1 & $88(55)$ & $12(32)$ & $37(67)$ & $36(62)$ & & & \\
\hline 2 or 3 & $73(45)$ & $25(68)$ & $18(33)$ & $22(38)$ & $7.0 \times 10^{-3}$ & $4.4 \times 10^{-3}$ & 0.22 \\
\hline \multicolumn{8}{|l|}{ In situ } \\
\hline Absent & $125(78)$ & $17(46)$ & $45(83)$ & $50(86)$ & & & \\
\hline$\geq$ Present & $36(22)$ & $20(54)$ & $9(17)$ & $8(14)$ & $2.8 \times 10^{-5}$ & $8.5 \times 10^{-6}$ & 0.31 \\
\hline \multicolumn{8}{|l|}{ Lymphoid infiltrate } \\
\hline 0 & $5(2)$ & $3(8)$ & $0(0)$ & $3(5)$ & & & \\
\hline 1 & $77(48)$ & $24(65)$ & $6(11)$ & $19(33)$ & & & \\
\hline 2 & $64(40)$ & $6(16)$ & $13(24)$ & $21(36)$ & & & \\
\hline 3 & $15(9)$ & $4(11)$ & $35(65)$ & $15(26)$ & $1.8 \times 10^{-15}$ & $2.0 \times 10^{-3}$ & $1.1 \times 10^{-13}$ \\
\hline \multicolumn{8}{|l|}{ Lobulitis } \\
\hline 0 or 1 & $56(47)$ & $14(64)$ & $19(43)$ & $13(37)$ & & & \\
\hline 2 & $40(34)$ & $6(27)$ & $16(36)$ & $13(37)$ & & & \\
\hline 3 & 22 (19) & $2(9)$ & $9(20)$ & $9(26)$ & 0.59 & 0.20 & 0.84 \\
\hline
\end{tabular}


Table 1 continued

\begin{tabular}{|c|c|c|c|c|c|c|c|}
\hline & $\begin{array}{l}\mathrm{BL} \\
n(\%) \\
N=161\end{array}$ & $\begin{array}{l}\text { LAR } \\
N(\%) \\
N=37\end{array}$ & $\begin{array}{l}\mathrm{IM} \\
N(\%) \\
N=55\end{array}$ & $\begin{array}{l}\text { STR } \\
n(\%) \\
N=58\end{array}$ & $\begin{array}{l}p \text {-value } \\
\text { four subtypes }\end{array}$ & $\begin{array}{l}p \text {-value } \\
\mathrm{B} \text { versus } \mathrm{NB}^{\mathrm{a}}\end{array}$ & $\begin{array}{l}p \text {-value } \\
\text { BL, IM, STR }\end{array}$ \\
\hline \multicolumn{8}{|l|}{ Involution } \\
\hline Incomplete & $66(52)$ & $8(0.31)$ & $33(75)$ & $20(54)$ & & & \\
\hline Complete & $60(48)$ & $18(69)$ & $11(25)$ & $17(46)$ & $3.5 \times 10^{-3}$ & 0.018 & 0.030 \\
\hline Age $[$ mean $(\mathrm{SD})]$ & $50.4(14.8)$ & $62.2(13.7)$ & $50.4(13.2)$ & $51.1(14.9)$ & $1.2 \times 10^{-7}$ & $1.5 \times 10^{-8}$ & 0.90 \\
\hline
\end{tabular}

${ }^{a}$ Basal versus non-basal

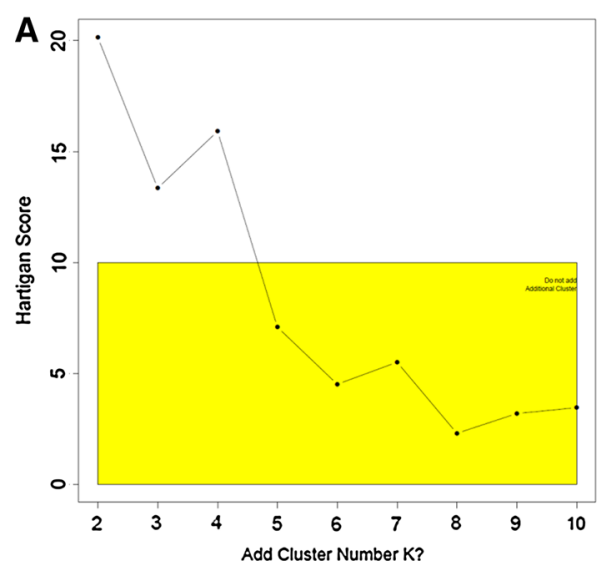

Fig. 1 Clustering robustness using 2158 agnostic probes. a A plot of Hartigan score values from the Engelman-Hartigan test for two through ten clusters. The yellow-highlighted area indicates the threshold below which additional clusters should not be added.

possibility of six TN subtypes (Table S10), no distinguishing pathways or ontologies were observed between two candidate BL subtypes or two candidate STR subtypes (Table S11). Thus, while the four subtypes are similar to those described previously [6, 7], we were unable to duplicate the presence of six subtypes of TN breast cancer in this unsupervised analysis.

\section{Histopathologic features among $\mathrm{TN}$ subtypes}

TN tumors have several distinctive histopathologic characteristics that capture differences in tumor cell behavior and the tumor microenvironment. We evaluated 310 TN tumors for 11 histopathological features (Table S5). The TN tumors were most commonly classified as undifferentiated adenocarcinomas (37\%), but several rare tumors including adenoid cystic carcinomas, apocrine adenocarcinomas, metaplastic carcinomas, and medullary carcinomas were also observed (Table S6), with LAR enrichment of apocrine adenocarcinomas and IM enrichment of medullary carcinomas. Significant differences in the distribution of all histopathological features except lobulitis by TN subtype b The consensus cumulative distribution functions (CDF) for each solution from two to ten clusters. c The delta area, or the relative change in the area under the consensus CDF curve for each solution from two to ten clusters

were observed (Table 1). These associations were driven largely by differences between the LAR subtype and the BL, IM, and STR subtypes (Table 1). When restricting to the BL, IM, and STR subtypes, only necrosis $\left(p=4.5 \times 10^{-5}\right)$, lymphoid infiltrate $\left(p=1.1 \times 10^{-13}\right)$, and involution $(p=0.03)$ were significantly associated with subtype (Table 1). The degree to which histopathologic features were correlated was variable (Table S12). As expected grade and mitotic index showed the highest correlation $(r=0.73)$. Age was also positively correlated with involution, where breast cancer cases with complete involution were on average 10 years older than those with incomplete involution (complete mean $=60.5$ years; incomplete mean $=$ 48.0 years).

\section{Molecular TN subtypes based on histopathology}

Given that we were unable to recapitulate the Lehmann subtypes in an unsupervised analysis, we hypothesized that genes related to tumor cell behavior and tumor microenvironment are integral to the identification of TN molecular subtypes. Thus, we next utilized genes associated with 10 


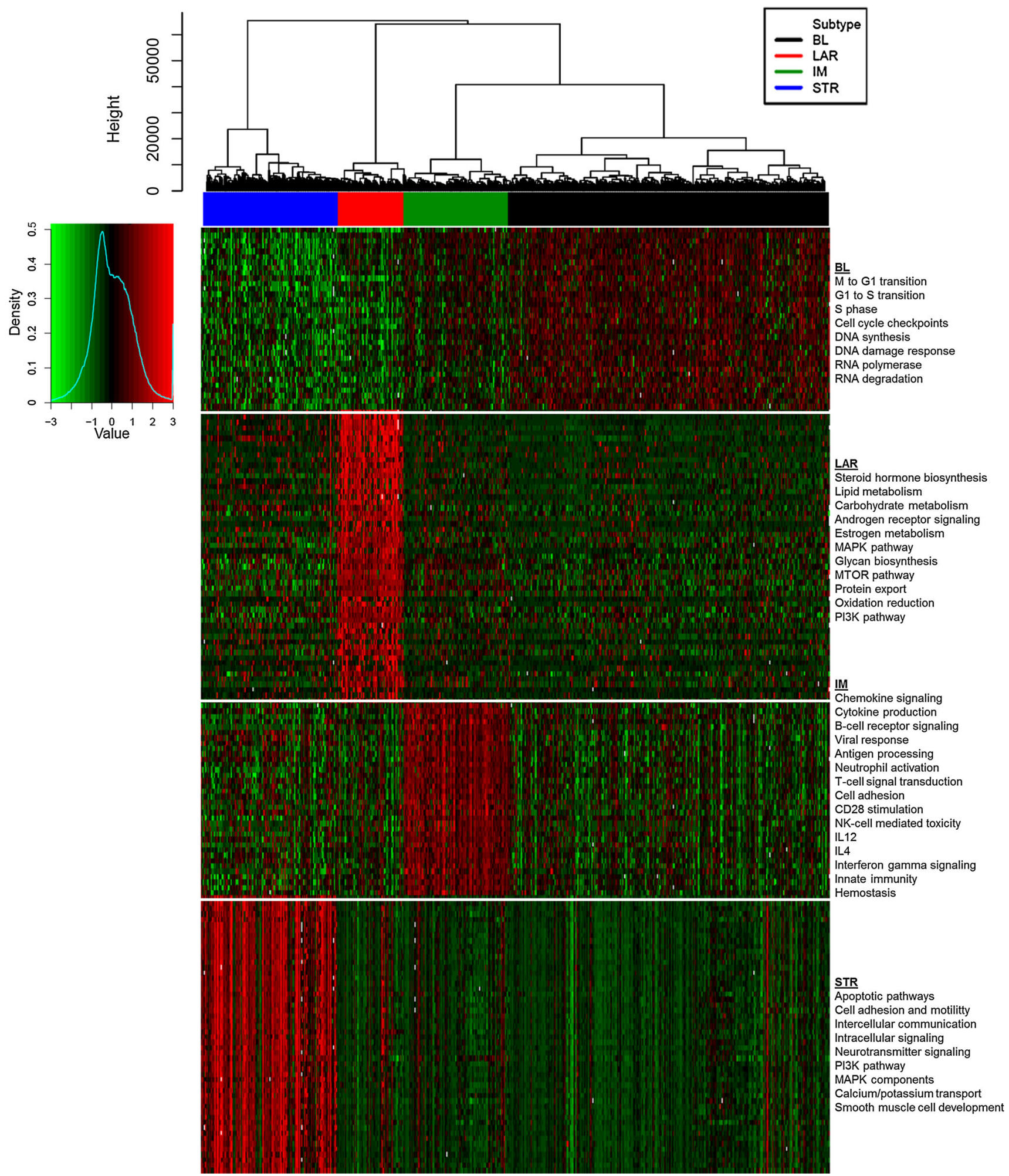

Fig. 2 Agnostic TN subtypes. A heatmap of the 177 genes that were significantly different across four agnostic TN subtypes. Red indicates up-regulated genes; green represents down-regulated genes compared to the mean. Each of the four subtypes is clustered as shown by the dendrogram and samples are color coded by subtype: black $\mathrm{BL}$, red LAR, green IM, blue STR. Enriched ontologies by GSEA corresponding to each of the four subtypes are listed next to the genes that were significantly up-regulated in clusters 
histopathologic features, excluding tumor cell type, in a hypothesis-driven clustering analysis of TN tumors. Within the 310 samples for which histopathologic data were available, we identified 2776 unique probes significantly associated with each of the ten features (Table S7). Hierarchical clustering for all $593 \mathrm{TN}$ tumors using these 2776 probes identified six groups (Table 2; Fig. 3a). This was confirmed by analysis of sample classification robustness using consensus clustering (Fig. 3b, c). The six groups are hereafter referred using the prefix "P-" to distinguish them from the four original TN clusters and the Lehmann subtype assignments.

GSEA showed strong similarities between these six phenotype-driven clusters and the Lehmann subtypes (Table S13; Fig. 4). There was substantial although imperfect agreement between phenotype-driven clusters and Lehmann subtype assignments for all groups except for the P-BL1 subtype $(\kappa=0.75,95 \%$ confidence interval 0.70-0.80), where tumors were assigned as L-BL1 (38 \%), L-BL2 (38 \%), and L-IM (23\%) using Lehmann centroid genes. Breast cancer cases in the P-LAR subtype were older (mean $=62.7)$ than those in all other subtypes $($ mean $=50.6)\left(p=2.1 \times 10^{-7}\right)$. Compared to the previous agnostic analysis resulting in only four subtypes, we identified a second BL and a second STR group. The P-BL2 subtype is distinguished from the P-BL1 subtype by the overexpression of cell motility/adhesion and glycolysis/ gluconeogenesis pathways, and by the relative lack of expression of inflammation, antigen presentation, and adaptive immunity genes (Fig. 4). The P-STR1 subtype is distinguishable from the P-STR2 subtype largely by the overexpression of a wide range of immunomodulatory pathways, while the P-STR2 subtype is enriched for MAPK components, PI3K, NFKB, and smooth muscle cell development pathways (Fig. 4). Furthermore, overexpression of the CD3, interferon gamma (IFGN), and IL10Th1 and Th2 cell markers that regulate transcription of innate and adaptive immune response genes including the PD-L1 marker associated with increased $\mathrm{T}$-cell cytotoxic immune response in basal breast cancers [29], was observed among the P-IM, P-BL1, and P-STR1 subtypes (Fig. S10). Finally, AR and AR targets were substantially overexpressed among the P-LAR group of TN tumors ( $n=58,9.8 \%$ ) (Fig. S11). We utilized SAM to identify the probes $(n=185)$ most strongly associated with these six subtypes (Table S8).

\section{Histopathologic features among pathology-based TN subtypes}

The distribution of histopathologic features across the six phenotype-driven subtypes was evaluated to better understand how individual features were associated with each subtype (Table 2). As before, all features were significantly associated with TN subtypes except for lobulitis (Tables 2, S14). Apocrine adenocarcinomas and medullary carcinomas were again more common among the P-LAR $\left(p=6.9 \times 10^{-6}\right)$ and P-IM $\left(p=2.9 \times 10^{-5}\right)$ subtypes. In addition, undifferentiated carcinomas were overrepresented among the P-BL1 subtype and underrepresented among the P-LAR subtype $(p=8.0 \times$ $\left.10^{-9}\right)$. Mitotic index, grade, growth pattern, necrosis, fibrosis, and lymphoid infiltrate were all significantly associated with non-LAR TN subtypes (Tables 2, S15).

We used a lasso-based multinomial regression model to evaluate the combined effects of histopathologic features and age that best predicted each of the six subtypes (Fig. S12; Table S16). Each subtype had a unique pattern of features that characterized membership. Lymphoid infiltrate was the only variable that was predictive of each subtype, where it was a positive predictor of P-BL1, P-IM, and P-STR1 subtypes and a negative predictor of P-BL2, P-LAR, and P-STR2 subtypes. The presence of necrosis and higher mitotic index were positive predictors of both P-BL subtypes, but these two groups were distinguished by the absence of fibrosis among P-BL1 tumors, the presence of trabecular pattern in P-BL2 tumors, and inverse relationships with lymphoid infiltrate. The two P-STR groups shared no common predictors, where P-STR1 was only predicted by lymphoid infiltrate and absence of DCIS; in contrast, P-STR2 was negatively predicted by grade, mitotic index, and lymphoid infiltrate and positively predicted by fibrosis. Lymphoid infiltrate was the strongest predictor of the P-IM subtype, along with lower rates of necrosis, DCIS, and involution. The P-LAR subtype was distinct in that it was associated with lower grade, older age, and higher rates of DCIS and complete involution.

We then evaluated the multivariate relationships between each gene accounting for histopathologic features and age to identify the features driving the 185-gene signature (Table S17). The majority of genes $(n=127)$ were significantly associated with a single feature in the multivariate models, with no more than three features predicting any single gene $(p<0.01)$. Lymphoid infiltrate and necrosis were the strongest drivers of this 185-gene signature, where lymphoid infiltrate was associated with $35 \%$ of genes and necrosis was associated with $38 \%$ of genes. Age, DCIS, fibrosis, and mitotic index were associated with $12-15 \%$ of genes, while lobulitis, trabecular pattern, and grade had negligible impact on the signature. These patterns further suggest that TN tumor heterogeneity is best described by the integration of histopathologic features and expression patterns of key pathways.

\section{Cancer predisposition genes}

To further characterize these six subtypes in terms of potentially targetable pathways, germline mutations in 
Table 2 Distribution of intrinsic subtypes and histopathologic features among six phenotype-driven subtypes

\begin{tabular}{|c|c|c|c|c|c|c|c|}
\hline & $\begin{array}{l}\text { P-BL1 } \\
n(\%) \\
N=161\end{array}$ & $\begin{array}{l}\text { P-BL2 } \\
n(\%) \\
N=158\end{array}$ & $\begin{array}{l}\text { P-LAR } \\
n(\%) \\
N=58\end{array}$ & $\begin{array}{l}\text { P-IM } \\
n(\%) \\
N=129\end{array}$ & $\begin{array}{l}\text { P-STR1 } \\
n(\%) \\
N=50\end{array}$ & $\begin{array}{l}\text { P-STR2 } \\
n(\%) \\
N=37\end{array}$ & $p$-value \\
\hline \multicolumn{8}{|l|}{ Agnostic subtype } \\
\hline BL & $135(84)$ & $129(82)$ & $7(12)$ & $17(13)$ & $8(16)$ & $5(13)$ & \\
\hline LAR & $0(0)$ & $2(1)$ & $43(74)$ & $14(11)$ & $0(0)$ & $4(11)$ & \\
\hline IM & $17(11)$ & $0(0)$ & $4(7)$ & $77(60)$ & $2(4)$ & $0(0)$ & \\
\hline STR & $9(5)$ & $27(17)$ & $4(7)$ & $21(16)$ & $40(80)$ & $28(76)$ & $3.2 \times 10^{-147}$ \\
\hline \multicolumn{8}{|l|}{ PAM50 subtype } \\
\hline Basal & $155(96)$ & $146(92)$ & $4(7)$ & $84(65)$ & $47(94)$ & $19(51)$ & \\
\hline HER2-enriched & $3(2)$ & $1(1)$ & $16(28)$ & $9(7)$ & $2(4)$ & $4(11)$ & \\
\hline Luminal A & $0(0)$ & $0(0)$ & $11(19)$ & $4(3)$ & $0(0)$ & $4(11)$ & \\
\hline Luminal B & $1(1)$ & $4(3)$ & $6(10)$ & $2(1)$ & $1(2)$ & $1(3)$ & \\
\hline Normal-like & $2(1)$ & $7(4)$ & $21(36)$ & $30(23)$ & $0(0)$ & $9(24)$ & $7.0 \times 10^{-47}$ \\
\hline \multicolumn{8}{|l|}{ Lehmann subtype } \\
\hline L-BL1 & $61(38)$ & $6(4)$ & $0(0)$ & $5(4)$ & $6(12)$ & $0(0)$ & \\
\hline L-BL2 & $61(38)$ & $133(84)$ & 7 (12) & $4(3)$ & $2(4)$ & $8(22)$ & \\
\hline L-LAR & $0(0)$ & $1(1)$ & $48(83)$ & $13(10)$ & $0(0)$ & $5(14)$ & \\
\hline L-IM & $37(23)$ & $4(3)$ & $3(5)$ & $96(74)$ & $1(2)$ & $0(0)$ & \\
\hline L-M & $1(1)$ & $14(9)$ & $0(0)$ & $8(6)$ & $37(74)$ & $0(0)$ & \\
\hline \multirow[t]{2}{*}{ L-MSL } & $1(1)$ & $0(0)$ & $0(0)$ & $3(2)$ & $4(8)$ & $24(65)$ & $5.6 \times 10^{-98}$ \\
\hline & $\begin{array}{l}\text { P-BL1 } \\
n(\%) \\
N=86\end{array}$ & $\begin{array}{l}\text { P-BL2 } \\
n(\%) \\
N=85\end{array}$ & $\begin{array}{l}\text { P-LAR } \\
n(\%) \\
N=37\end{array}$ & $\begin{array}{l}\text { P-IM } \\
n(\%) \\
N=68\end{array}$ & $\begin{array}{l}\text { P-STR1 } \\
n(\%) \\
N=21\end{array}$ & $\begin{array}{l}\text { P-STR2 } \\
n(\%) \\
N=14\end{array}$ & $p$-value \\
\hline \multicolumn{8}{|l|}{ Mitotic index } \\
\hline 1 or 2 & $8(9)$ & $10(12)$ & $18(49)$ & $14(21)$ & $1(5)$ & $11(79)$ & \\
\hline 3 & $78(91)$ & $75(88)$ & $19(51)$ & $54(79)$ & $20(95)$ & $3(21)$ & $4.8 \times 10^{-12}$ \\
\hline \multicolumn{8}{|l|}{ Grade } \\
\hline 1 or 2 & $4(5)$ & $4(5)$ & $12(32)$ & $7(10)$ & $1(5)$ & $8(57)$ & \\
\hline 3 & $82(95)$ & $81(95)$ & $25(68)$ & $61(90)$ & $20(95)$ & $6(43)$ & $3.2 \times 10^{-10}$ \\
\hline \multicolumn{8}{|l|}{ Trabecular pattern } \\
\hline Absent & $45(52)$ & $46(54)$ & $33(89)$ & $49(72)$ & $11(52)$ & $12(86)$ & \\
\hline$\geq$ Present & $41(48)$ & $39(46)$ & $4(11)$ & $19(28)$ & $10(48)$ & $2(14)$ & $1.8 \times 10^{-4}$ \\
\hline \multicolumn{8}{|l|}{ Growth pattern } \\
\hline Epicenter & $62(72)$ & $58(68)$ & $11(30)$ & $42(63)$ & $16(76)$ & $2(14)$ & \\
\hline Infiltrative & $18(21)$ & $25(29)$ & $23(62)$ & $20(30)$ & $5(24)$ & $9(64)$ & \\
\hline Multifocal & $6(7)$ & $2(2)$ & $3(8)$ & $5(7)$ & $0(0)$ & $3(21)$ & $7.1 \times 10^{-6}$ \\
\hline \multicolumn{8}{|l|}{ Necrosis } \\
\hline Absent & $25(29)$ & $22(26)$ & $26(70)$ & 47 (69) & $11(52)$ & $11(79)$ & \\
\hline$\geq$ Present & $61(71)$ & $63(74)$ & $11(30)$ & $21(31)$ & $10(48)$ & $3(21)$ & $2.6 \times 10^{-10}$ \\
\hline \multicolumn{8}{|l|}{ Fibrosis } \\
\hline 0 or 1 & $60(70)$ & $46(54)$ & $8(22)$ & $41(60)$ & $16(76)$ & $2(14)$ & \\
\hline 2 or 3 & $26(30)$ & $39(46)$ & $29(78)$ & $27(40)$ & $5(24)$ & $12(86)$ & $3.3 \times 10^{-7}$ \\
\hline \multicolumn{8}{|l|}{ In situ } \\
\hline Absent & $73(85)$ & $64(75)$ & $16(43)$ & $53(79)$ & $21(100)$ & $10(71)$ & \\
\hline$\geq$ Present & $13(15)$ & $21(25)$ & $21(57)$ & $14(21)$ & $0(0)$ & $4(29)$ & $3.7 \times 10^{-6}$ \\
\hline \multicolumn{8}{|c|}{ Lymphoid infiltrate } \\
\hline 0 & $0(0)$ & $4(5)$ & $4(11)$ & $0(0)$ & $0(0)$ & $3(21)$ & \\
\hline 1 & $20(23)$ & $59(69)$ & $28(76)$ & $10(15)$ & $0(0)$ & $9(64)$ & \\
\hline 2 & $49(57)$ & $21(25)$ & $2(5)$ & $23(34)$ & $7(33)$ & $2(14)$ & \\
\hline
\end{tabular}


Table 2 continued

\begin{tabular}{|c|c|c|c|c|c|c|c|}
\hline & $\begin{array}{l}\text { P-BL1 } \\
n(\%) \\
N=86\end{array}$ & $\begin{array}{l}\text { P-BL2 } \\
n(\%) \\
N=85\end{array}$ & $\begin{array}{l}\text { P-LAR } \\
n(\%) \\
N=37\end{array}$ & $\begin{array}{l}\text { P-IM } \\
n(\%) \\
N=68\end{array}$ & $\begin{array}{l}\text { P-STR1 } \\
n(\%) \\
N=21\end{array}$ & $\begin{array}{l}\text { P-STR2 } \\
n(\%) \\
N=14\end{array}$ & $p$-value \\
\hline 3 & $17(20)$ & $1(1)$ & $3(8)$ & $34(51)$ & $14(67)$ & $0(0)$ & $4.0 \times 10^{-29}$ \\
\hline \multicolumn{8}{|l|}{ Lobulitis } \\
\hline 0 or 1 & $27(40)$ & $30(55)$ & $15(65)$ & $19(39)$ & $7(44)$ & $4(5)$ & \\
\hline 2 & $26(38)$ & $19(35)$ & $4(17)$ & $19(39)$ & $3(19)$ & $4(5)$ & \\
\hline 3 & $15(22)$ & $6(11)$ & $4(17)$ & $11(22)$ & $6(38)$ & $0(0)$ & 0.13 \\
\hline \multicolumn{8}{|l|}{ Involution } \\
\hline Incomplete & $36(51)$ & $36(59)$ & $7(27)$ & $36(71)$ & $10(63)$ & $2(22)$ & \\
\hline Complete & $34(49)$ & $25(41)$ & $19(73)$ & $15(29)$ & $6(38)$ & $7(78)$ & $2.6 \times 10^{-3}$ \\
\hline Age [mean (SD)] & $49.8(14.4)$ & $49.3(14.1)$ & $62.7(15.1)$ & $52.4(14.0)$ & $49.7(14.5)$ & $55(14.8)$ & $4.2 \times 10^{-8}$ \\
\hline
\end{tabular}
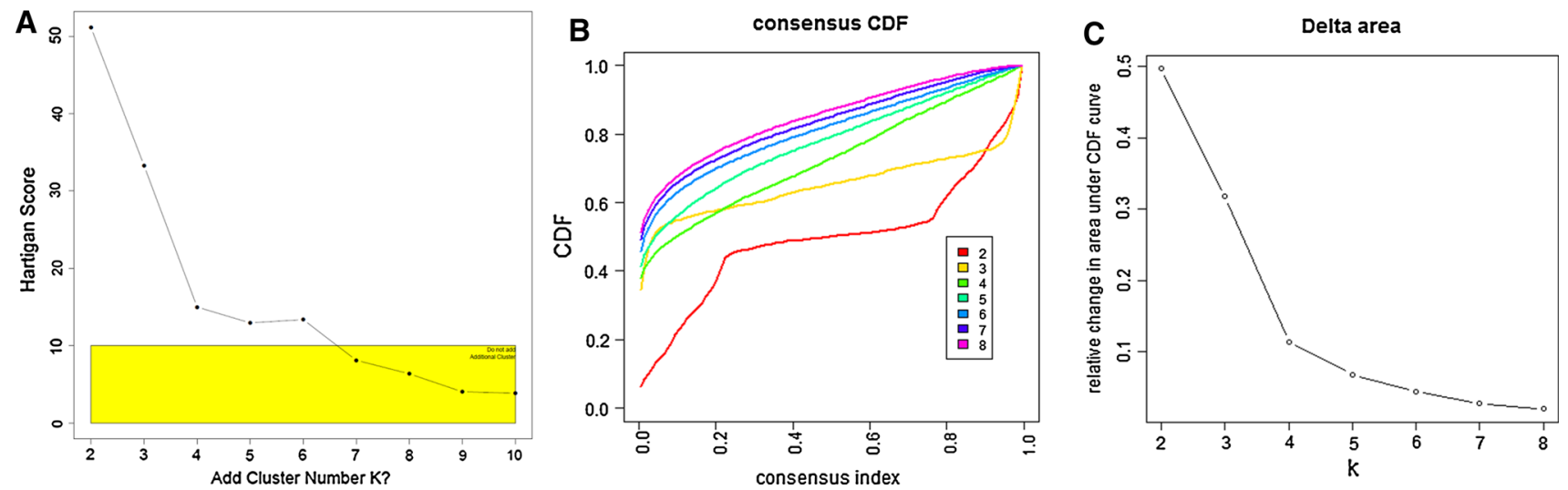

Fig. 3 Clustering robustness using 2776 pathology-based probes. a A plot of Hartigan score values from the Engelman-Hartigan test for two through ten clusters. The yellow-highlighted area indicates the threshold below which additional clusters should not be added. b The

breast cancer susceptibility genes were evaluated by TN subtype [27]. The distribution of pathology-based TN subtypes in the $156 \mathrm{TN}$ tumors with mutation screening data was comparable to the overall group of 593 tumors (Table S18). A total of $21(13.5 \%)$ pathogenic mutations were identified in six DNA repair genes: BRCA1, BRCA2, $B A R D 1, R A D 50, B R I P 1$, and PALB2 (Table S18), which is consistent with the $14.6 \%$ of $\mathrm{TN}$ cases found to carry germline mutations in other larger studies [27, 30]. The mean age at diagnosis for women with germline mutations (mean $=40.3$ years) was significantly lower than for women without germline mutations (mean $=48.1$ years) ( $p=0.0013)$. Consistent with the observation that DNA repair pathways are integral to the P-BL1 and P-BL2 subtypes, these two subtypes had the highest proportion of individuals with germline mutations (17.8-22.5\%). Interestingly, although the number of P-STR2 tumors screened was small $(n=9)$, a relatively large proportion of these tumors contained mutations in BRCAl and PALB2 consensus cumulative distribution functions (CDF) for each solution from two to ten clusters. c The delta area, or the relative change in the area under the consensus CDF curve for each solution from two to ten clusters

(22.2\%). In contrast, only $5.9 \%$ of the P-IM subtype had mutations in BRCA1 and BRCA2. No mutations were identified in either the P-LAR or the P-STR1 subtypes. In combination with the histopathologic features described above, these patterns of germline mutations in DNA repair genes provide further evidence for the heterogeneity of TN tumors.

\section{Discussion}

In this analysis of $593 \mathrm{TN}$ tumors, we identified six distinct TN molecular subtypes by expression profiling and showed that these subtypes are characterized by genes related to histopathologic features that reflect heterogeneity in tumor architecture, cell structure and behavior, and tumor microenvironment. While our six phenotype-driven subtypes were largely similar to those described by Lehmann, et al. when comparing subtype-specific pathway enrichment, 


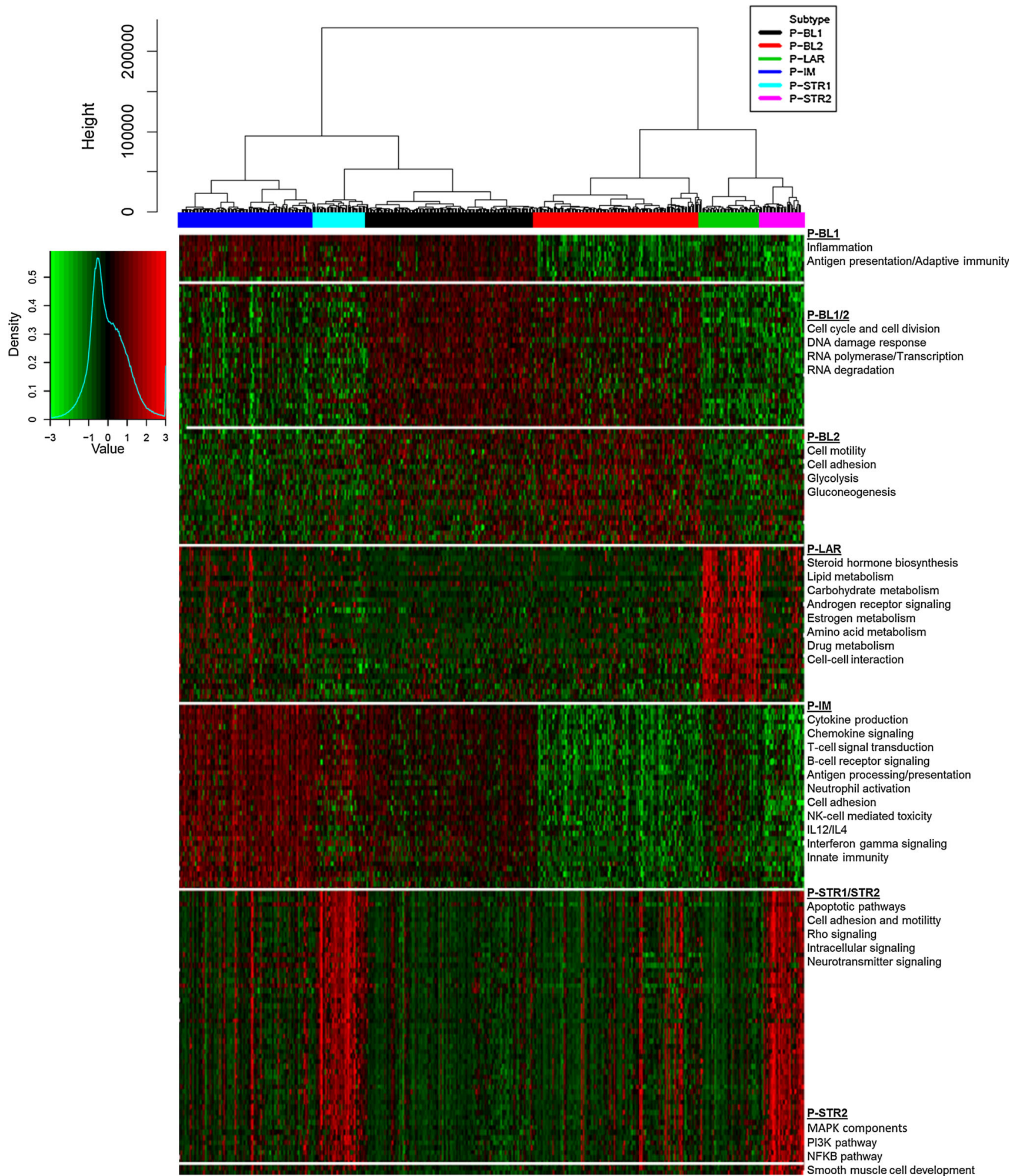

Fig. 4 Phenotype-driven TN subtypes. A heatmap of the 185 genes that were significantly different across the six phenotype-driven TN subtypes. Red indicates up-regulated genes; green represents downregulated genes compared to the mean. Each of the six subtypes is clustered as shown by the dendrogram and samples are color coded by subtype: black P-BL1, red P-BL2, green P-LAR, blue P-IM, cyan P-STR1, purple P-STR2. Enriched ontologies by GSEA corresponding to each of the six subtypes are listed next to the group of genes that were significantly up-regulated in clusters 
there were differences between the two classification schemes. In particular, differences between the two BL subtypes and two STR subtypes in the current study were dependent on the integration of signaling pathways associated with pathology features. Specifically, the up-regulation of immune pathways was a distinguishing feature of both the P-BL1 and P-STR1 subtypes, consistent with lymphocytic infiltration histopathological patterns across the six $\mathrm{TN}$ subtypes. However, mitotic index, grade, growth pattern, necrosis, fibrosis were also driving factors in the differences in histopathological patterns between these subtypes.

Basal-like breast cancers are known to have higher grade and mitotic index and have greater presence of necrosis, tumor infiltrating lymphocytes, and incomplete involution compared to non-basal breast cancer subtypes [16]. We validate this in the current study by showing that these differences exist between the P-LAR and basal-like subtypes. In addition, we show that these features are heterogeneous among basal-like subtypes. In particular, mitotic index and grade were low among the P-IM and P-STR2 subtypes, necrosis was substantially lower among P-IM and P-STR tumors, complete involution was highest among the P-STR2 subtype, and lymphoid infiltrate was highly variable across all basal-like subtypes. We further show for the first time that unique combinations of these features can be used to predict TN molecular subtype.

In a recent study of germline cancer predisposition gene mutations in $\mathrm{TN}$ cases, mutations in genes involved in homologous recombination (HR) accounted for $81 \%$ of all non-BRCA1/2 mutations identified [27], indicating that the perturbation of HRDNA repair may be particularly important for TN breast carcinogenesis. In light of this, it is not surprising that the 21 mutations identified in the 156 women included in the current study were all found in six HR genes (BRCA1, BRCA2, BRIP1, BARD1, PALB2, $R A D 50$ ) [31]. While it is known that DNA repair mutations are associated with the basal breast cancer molecular subtype [32], our data suggest that this effect may be limited to the development of the P-BL1, P-BL2, and possibly P-STR2 subtypes of TN breast cancer through disruption of the HR pathway.

A better understanding of the immune cells associated with each of these subtypes is particularly important considering the prognostic implications of lymphocytic infiltration in highly proliferative tumors such as TN breast cancers. The presence of $\mathrm{T}$ regulatory cells and tumorassociated macrophages has been correlated with negative effect on survival in pancreatic, liver, colorectal, and breast cancers [33-38]. In contrast, better overall and disease-free survival has been associated with increased infiltration of CD8+ cytotoxic T cells in colorectal, ovarian, hepatocellular, and breast cancers [39-42]. Cytokines associated with $\mathrm{T}$ helper cells, Th1 (IFN- $\gamma / \mathrm{CD} 3+$ ) and Th2 (IL10/
$\mathrm{CD} 3+$ ) cells have also been used to show that the relative levels of Th1/Th2 cells have prognostic implications for ovarian, non-small cell lung, and breast cancer [43-45]. Further studies that explore the extent to which these individual cell types, and the immune processes they represent, influence specific TN subtypes are necessary.

Another important implication of the identification of specific pathways up-regulated in TN subtypes is the possibility for the development of targeted therapies. The PD1/ PD-L1 pathway is a key inhibitor of the immune system that favors tumor progression [46-48]. PD-L1 expression is up-regulated specifically in basal breast tumors, and high expression has been associated with better metastasis-free and breast cancer-specific survival in basal breast tumors [29]. Clinical trials of melanoma, renal, lung, prostate, and bladder cancers investigating the use of anti-PD1 and antiPD-L1 agents suggest that blocking the PD1/PD-L1 pathway may restore anti-cancer immunity [49-51] in a number of tumors. The knowledge that PD1 and PD-L1 are upregulated in specific subtypes of $\mathrm{TN}$ breast cancer allows for more focused and hence better-designed clinical trials of anti-PD1/PD-L1 therapy in breast cancer and TN breast cancer. Beyond PD1/PD-L1, these data may identify additional targetable pathways that may lead to the development of new therapies specific to TN breast cancer subtypes.

In conclusion, we have shown that TN tumors are highly heterogeneous, as determined by both gene expression and pathology. The integration of these data with other genomic and epidemiologic data is integral to a better understanding of these aggressive tumors. The utilization of tools such as targeted sequencing and DNA copy number variation in combination with gene expression and pathology will help to further define TN subtypes and to identify potentially targetable biomarkers. It is also of particular importance to characterize the implications of these $\mathrm{TN}$ subtypes for response to treatment, disease progression, and survival. Further studies are necessary to explore the full extent of heterogeneity in TN tumors and the associated clinical implications.

Acknowledgments HEBCS: Dario Greco, Tuomas Heikkinen, Kristiina Aittomäki. KBCP thanks Eija Myöhänen, Helena Kemiläinen, and Aija Parkkinen for their skillful technical assistance. We thank all study participants, clinicians, family doctors, researchers, and technicians for their contributions and commitment to this study. SBCS would like to thank Sue Higham, Helen Cramp, Ian Brock, Sabapathy Balasubramanian, Malcolm W.R. Reed, and Dan Connley. NBHS thanks study participants and research staff for their contributions and commitment to this study. POSH thanks Linda Haywood for her technical support.

Financial support The TNBCC and this tumor study was supported by the Breast Cancer Research Foundation, NIH Grants CA116167, CA192393, and an NIH specialized program of research excellence (SPORE) (P50 CA116201) in breast cancer to Mayo Clinic. 
K. Purrington completed this work partially as a Mayo Cancer Genetic Epidemiology Training Program (CA92049-03) fellow. The Australian Breast Cancer Tissue Bank is generously supported by the National Health and Medical Research Council of Australia, The Cancer Institute NSW, and the National Breast Cancer Foundation. MCCS cohort recruitment was funded by VicHealth and Cancer Council Victoria. The MCCS was further supported by Australian NHMRC Grants 209057, 251553, and 504711 and by infrastructure provided by Cancer Council Victoria. Cases and their vital status were ascertained through the Victorian Cancer Registry (VCR). HeCOG research has been co-financed by the European Union (European Social Fund) and Greek national funds through the operational program Education and Lifelong Learning of the National Strategic Reference Framework Research Funding Program: Thales-investing in knowledge society through the European Social Fund. The HEBCS was financially supported by the Helsinki University Central Hospital Research Fund, Academy of Finland (266528), the Finnish Cancer Society, and the Sigrid Juselius Foundation. KBCPstudy was funded by grants from the Finnish Cancer Society, the special Governmental EVO Research Fund of Kuopio University Hospital (grants 53125, 53127, and 53132), and strategic funding of the University of Eastern Finland. SKKDKFZS is supported by the DKFZ. The SBCS was supported by Yorkshire Cancer Research S295, S299, S305PA, and Sheffield Experimental Cancer Medicine Centre. The Nashville Breast Health Study (NBHS) was supported by National Institutes of Health (Grant R01CA100374). POSH is supported by C1275/ A11699, C1275/A9896, and C22524.

\section{Compliance with ethical standards}

Conflict of interest The authors declare that they have no conflicts of interest.

\section{References}

1. Foulkes WD, Smith IE, Reis-Filho JS (2010) Triple-negative breast cancer. N Engl J Med 363(20):1938-1948. doi:10.1056/ NEJMra1001389

2. American Cancer Society. Breast Cancer Facts \& Figures, 2011-2012 (2012). American Cancer Society, Atlanta

3. Perou CM (2010) Molecular stratification of triple-negative breast cancers. Oncologist 15(Suppl 5):39-48. doi:10.1634/ theoncologist.2010-S5-39

4. Perou CM, Sorlie T, Eisen MB, van de Rijn M, Jeffrey SS, Rees CA, Pollack JR, Ross DT, Johnsen H, Akslen LA, Fluge O, Pergamenschikov A, Williams C, Zhu SX, Lonning PE, Borresen-Dale AL, Brown PO, Botstein D (2000) Molecular portraits of human breast tumours. Nature 406(6797):747-752. doi:10. $1038 / 35021093$

5. Sorlie T, Perou CM, Tibshirani R, Aas T, Geisler S, Johnsen H, Hastie T, Eisen MB, van de Rijn M, Jeffrey SS, Thorsen T, Quist H, Matese JC, Brown PO, Botstein D, Eystein Lonning P, Borresen-Dale AL (2001) Gene expression patterns of breast carcinomas distinguish tumor subclasses with clinical implications. Proc Natl Acad Sci USA 98(19):10869-10874

6. Lehmann BD, Bauer JA, Chen X, Sanders ME, Chakravarthy AB, Shyr Y, Pietenpol JA (2011) Identification of human triple-negative breast cancer subtypes and preclinical models for selection of targeted therapies. J Clin Invest 121(7):2750-2767

7. Prat A, Adamo B, Cheang MC, Anders CK, Carey LA, Perou CM (2013) Molecular characterization of basal-like and non-basallike triple-negative breast cancer. Oncologist 18(2):123-133. doi:10.1634/theoncologist.2012-0397
8. Loi S, Michiels S, Salgado R, Sirtaine N, Jose V, Fumagalli D, Kellokumpu-Lehtinen PL, Bono P, Kataja V, Desmedt C, Piccart MJ, Loibl S, Denkert C, Smyth MJ, Joensuu H, Sotiriou C (2014) Tumor infiltrating lymphocytes are prognostic in triple negative breast cancer and predictive for trastuzumab benefit in early breast cancer: results from the FinHER trial. Ann Oncol 25(8):1544-1550. doi:10.1093/annonc/mdu112

9. Loi S, Sirtaine N, Piette F, Salgado R, Viale G, Van Eenoo F, Rouas G, Francis P, Crown JP, Hitre E, de Azambuja E, Quinaux E, Di Leo A, Michiels S, Piccart MJ, Sotiriou C (2013) Prognostic and predictive value of tumor-infiltrating lymphocytes in a phase III randomized adjuvant breast cancer trial in node-positive breast cancer comparing the addition of docetaxel to doxorubicin with doxorubicin-based chemotherapy: BIG 02-98. J Clin Oncol 31(7):860-867. doi:10.1200/JCO.2011.41.0902

10. Heinecke JL, Ridnour LA, Cheng RY, Switzer CH, Lizardo MM, Khanna C, Glynn SA, Hussain SP, Young HA, Ambs S, Wink DA (2014) Tumor microenvironment-based feed-forward regulation of NOS2 in breast cancer progression. Proc Natl Acad Sci USA 111(17):6323-6328. doi:10.1073/pnas.1401799111

11. Hasebe $T$, Iwasaki $M$, Akashi-Tanaka $S$, Hojo $T$, Shibata $T$, Sasajima Y, Kinoshita T, Tsuda H (2011) Atypical tumor-stromal fibroblasts in invasive ductal carcinoma of the breast. Am J Surg Pathol 35(3):325-336. doi:10.1097/PAS.0b013e31820afab9

12. Hasebe $T$ (2013) Tumor-stromal interactions in breast tumor progression-significance of histological heterogeneity of tumorstromal fibroblasts. Expert Opin Ther Targets 17(4):449-460. doi:10.1517/14728222.2013.757305

13. Masuda H, Baggerly KA, Wang Y, Zhang Y, Gonzalez-Angulo AM, Meric-Bernstam F, Valero V, Lehmann BD, Pietenpol JA, Hortobagyi GN, Symmans WF, Ueno NT (2013) Differential response to neoadjuvant chemotherapy among 7 triple-negative breast cancer molecular subtypes. Clin Cancer Res 19(19): 5533-5540. doi:10.1158/1078-0432.CCR-13-0799

14. Bauer KR, Brown M, Cress RD, Parise CA, Caggiano V (2007) Descriptive analysis of estrogen receptor (ER)-negative, progesterone receptor (PR)-negative, and HER2-negative invasive breast cancer, the so-called triple-negative phenotype: a population-based study from the California cancer Registry. Cancer 109(9):1721-1728. doi:10.1002/cncr.22618

15. Bonzanini M, Morelli L, Bonandini EM, Leonardi E, Pertile R, Dalla Palma P (2012) Cytologic features of triple-negative breast carcinoma. Cancer Cytopathol 120(6):401-409. doi:10.1002/ cncy. 21207

16. Livasy CA, Karaca G, Nanda R, Tretiakova MS, Olopade OI, Moore DT, Perou CM (2006) Phenotypic evaluation of the basallike subtype of invasive breast carcinoma. Mod Pathol 19(2):264-271. doi:10.1038/modpathol.3800528

17. Schmadeka R, Harmon BE, Singh M (2014) Triple-negative breast carcinoma: current and emerging concepts. Am J Clin Pathol 141(4):462-477. doi:10.1309/AJCPQN8GZ8SILKGN

18. Siddiq A, Couch FJ, Chen GK, Lindstrom S, Eccles D, Millikan RC, Michailidou K, Stram DO, Beckmann L, Kyong Rhie S, Ambrosone CB, Aittomaki K, Amiano P, Apicella C, Baglietto L, Bandera EV, Beckmann MW, Berg CD, Bernstein L, Blomqvist C, Brauch H, Brinton L, Bui QM, Buring JE, Buys SS, Campa D, Carpenter JE, Chasman DI, Chang-Claude J, Chen C, ClavelChapelon F, Cox A, Cross SS, Czene K, Deming SL, Diasio RB, Diver WR, Dunning AM, Durcan L, Ekici AB, Fasching PA, Feigelson HS, Fejerman L, Figueroa JD, Fletcher O, Flesch-Janys D, Gaudet MM, Gerty SM, Rodriguez-Gil JL, Giles GG, van Gils CH, Godwin AK, Graham N, Greco D, Hall P, Hankinson SE, Hartmann A, Hein R, Heinz J, Hoover RN, Hopper JL, Hu JJ, Huntsman S, Ingles SA, Irwanto A, Isaacs C, Jacobs KB, John EM, Justenhoven C, Kaaks R, Kolonel LN, Coetzee GA, Lathrop M, Le Marchand L, Lee AM, Lee IM, Lesnick T, Lichtner P, Liu 
J, Lund E, Makalic E, Martin NG, McLean CA, Meijers-Heijboer H, Meindl A, Miron P, Monroe KR, Montgomery GW, MullerMyhsok B, Nickels S, Nyante SJ, Olswold C, Overvad K, Palli D, Park DJ, Palmer JR, Pathak H, Peto J, Pharoah P, Rahman N, Rivadeneira F, Schmidt DF, Schmutzler RK, Slager S, Southey MC, Stevens KN, Sinn HP, Press MF, Ross E, Riboli E, Ridker PM, Schumacher FR, Severi G, Dos Santos Silva I, Stone J, Sund M, Tapper WJ, Thun MJ, Travis RC, Turnbull C, Uitterlinden AG, Waisfisz Q, Wang X, Wang Z, Weaver J, Schulz-Wendtland R, Wilkens LR, Van Den Berg D, Zheng W, Ziegler RG, Ziv E, Nevanlinna H, Easton DF, Hunter DJ, Henderson BE, Chanock SJ, Garcia-Closas M, Kraft P, Haiman CA, Vachon CM (2012) A meta-analysis of genome-wide association studies of breast cancer identifies two novel susceptibility loci at $6 \mathrm{q} 14$ and $20 \mathrm{q} 11$. Hum Mol Genet 21(24):5373-5384. doi:10.1093/hmg/dds381

19. Stevens KN, Vachon CM, Lee AM, Slager S, Lesnick T, Olswold C, Fasching PA, Miron P, Eccles D, Carpenter JE, Godwin AK, Ambrosone C, Winquist R, Brauch H, Schmidt MK, Cox A, Cross SS, Sawyer E, Hartmann A, Beckmann MW, Schulz-Wendtland R, Ekici AB, Tapper WJ, Gerty SM, Durcan L, Graham N, Hein R, Nickels S, Flesch-Janys D, Heinz J, Sinn HP, Konstantopoulou I, Fostira F, Pectasides D, Dimopoulos AM, Fountzilas G, Clarke CL, Balleine R, Olson JE, Fredericksen Z, Diasio RB, Pathak H, Ross E, Weaver J, Rudiger T, Forsti A, Dunnebier T, Ademuyiwa F, Kulkarni S, Pylkas K, Jukkola-Vuorinen A, Ko YD, Van Limbergen E, Janssen H, Peto J, Fletcher O, Giles GG, Baglietto L, Verhoef S, Tomlinson I, Kosma VM, Beesley J, Greco D, Blomqvist C, Irwanto A, Liu J, Blows FM, Dawson SJ, Margolin S, Mannermaa A, Martin NG, Montgomery GW, Lambrechts D, dos Santos Silva I, Severi G, Hamann U, Pharoah P, Easton DF, Chang-Claude J, Yannoukakos D, Nevanlinna H, Wang X, Couch FJ (2011) Common breast cancer susceptibility loci are associated with triplenegative breast cancer. Cancer Res 71(19):6240-6249. doi:10. 1158/0008-5472.CAN-11-1266

20. Yang XR, Chang-Claude J, Goode EL, Couch FJ, Nevanlinna H, Milne RL, Gaudet M, Schmidt MK, Broeks A, Cox A, Fasching PA, Hein R, Spurdle AB, Blows F, Driver K, Flesch-Janys D, Heinz J, Sinn P, Vrieling A, Heikkinen T, Aittomaki K, Heikkila P, Blomqvist C, Lissowska J, Peplonska B, Chanock S, Figueroa J, Brinton L, Hall P, Czene K, Humphreys K, Darabi H, Liu J, Van 't Veer LJ, van Leeuwen FE, Andrulis IL, Glendon G, Knight JA, Mulligan AM, O'Malley FP, Weerasooriya N, John EM, Beckmann MW, Hartmann A, Weihbrecht SB, Wachter DL, Jud SM, Loehberg CR, Baglietto L, English DR, Giles GG, McLean CA, Severi G, Lambrechts D, Vandorpe T, Weltens C, Paridaens R, Smeets A, Neven P, Wildiers H, Wang X, Olson JE, Cafourek V, Fredericksen Z, Kosel M, Vachon C, Cramp HE, Connley D, Cross SS, Balasubramanian SP, Reed MW, Dork T, Bremer M, Meyer A, Karstens JH, Ay A, Park-Simon TW, Hillemanns P, Arias Perez JI, Menendez Rodriguez P, Zamora P, Benitez J, Ko YD, Fischer HP, Hamann U, Pesch B, Bruning T, Justenhoven C, Brauch H, Eccles DM, Tapper WJ, Gerty SM, Sawyer EJ, Tomlinson IP, Jones A, Kerin M, Miller N, McInerney N, Anton-Culver H, Ziogas A, Shen CY, Hsiung CN, Wu PE, Yang SL, Yu JC, Chen ST, Hsu GC, Haiman CA, Henderson BE, Le Marchand L, Kolonel LN, Lindblom A, Margolin S, Jakubowska A, Lubinski J, Huzarski T, Byrski T, Gorski B, Gronwald J, Hooning MJ, Hollestelle A, van den Ouweland AM, Jager A, Kriege M, Tilanus-Linthorst MM, Collee M, WangGohrke S, Pylkas K, Jukkola-Vuorinen A, Mononen K, Grip M, Hirvikoski P, Winqvist R, Mannermaa A, Kosma VM, Kauppinen J, Kataja V, Auvinen P, Soini Y, Sironen R, Bojesen SE, Orsted DD, Kaur-Knudsen D, Flyger H, Nordestgaard BG, Holland H, Chenevix-Trench G, Manoukian S, Barile M, Radice P, Hankinson SE, Hunter DJ, Tamimi R, Sangrajrang S, Brennan P, McKay J, Odefrey F, Gaborieau V, Devilee P, Huijts PE,
Tollenaar RA, Seynaeve C, Dite GS, Apicella C, Hopper JL, Hammet F, Tsimiklis H, Smith LD, Southey MC, Humphreys MK, Easton D, Pharoah P, Sherman ME, Garcia-Closas M (2011) Associations of breast cancer risk factors with tumor subtypes: a pooled analysis from the Breast Cancer Association Consortium studies. J Natl Cancer Inst 103(3):250-263. doi:10.1093/jnci/ djq526

21. Mahoney DW, Therneau TM, Anderson SK, Jen J, Kocher JP, Reinholz MM, Perez EA, Eckel-Passow JE (2013) Quality assessment metrics for whole genome gene expression profiling of paraffin embedded samples. BMC Res Notes 6:33. doi:10. 1186/1756-0500-6-33

22. Parker JS, Mullins M, Cheang MC, Leung S, Voduc D, Vickery T, Davies S, Fauron C, He X, Hu Z, Quackenbush JF, Stijleman IJ, Palazzo J, Marron JS, Nobel AB, Mardis E, Nielsen TO, Ellis MJ, Perou CM, Bernard PS (2009) Supervised risk predictor of breast cancer based on intrinsic subtypes. J Clin Oncol 27(8):1160-1167. doi:10.1200/JCO.2008.18.1370

23. Subramanian A, Tamayo P, Mootha VK, Mukherjee S, Ebert BL, Gillette MA, Paulovich A, Pomeroy SL, Golub TR, Lander ES, Mesirov JP (2005) Gene set enrichment analysis: a knowledgebased approach for interpreting genome-wide expression profiles. Proc Natl Acad Sci USA 102(43):15545-15550. doi:10.1073/ pnas.0506580102

24. Mootha VK, Lindgren CM, Eriksson KF, Subramanian A, Sihag S, Lehar J, Puigserver P, Carlsson E, Ridderstrale M, Laurila E, Houstis N, Daly MJ, Patterson N, Mesirov JP, Golub TR, Tamayo P, Spiegelman B, Lander ES, Hirschhorn JN, Altshuler D, Groop LC (2003) PGC-1alpha-responsive genes involved in oxidative phosphorylation are coordinately downregulated in human diabetes. Nat Genet 34(3):267-273. doi:10.1038/ng1180

25. Ghosh K, Vachon CM, Pankratz VS, Vierkant RA, Anderson SS, Brandt KR, Visscher DW, Reynolds C, Frost MH, Hartmann LC (2010) Independent association of lobular involution and mammographic breast density with breast cancer risk. J Natl Cancer Inst 102(22):1716-1723. doi:10.1093/jnci/djq414

26. Milanese TR, Hartmann LC, Sellers TA, Frost MH, Vierkant RA, Maloney SD, Pankratz VS, Degnim AC, Vachon CM, Reynolds CA, Thompson RA, Melton LJ 3rd, Goode EL, Visscher DW (2006) Age-related lobular involution and risk of breast cancer. J Natl Cancer Inst 98(22):1600-1607. doi:10.1093/jnci/djj439

27. Couch FJ, Hart SN, Sharma P, Toland AE, Wang X, Miron P, Olson JE, Godwin AK, Pankratz VS, Olswold C, Slettedahl S, Hallberg E, Guidugli L, Davila JI, Beckmann MW, Janni W, Rack B, Ekici AB, Slamon DJ, Konstantopoulou I, Fostira F, Vratimos A, Fountzilas G, Pelttari LM, Tapper WJ, Durcan L, Cross SS, Pilarski R, Shapiro CL, Klemp J, Yao S, Garber J, Cox A, Brauch H, Ambrosone C, Nevanlinna H, Yannoukakos D, Slager SL, Vachon CM, Eccles DM, Fasching PA (2015) Inherited mutations in 17 breast cancer susceptibility genes among a large triple-negative breast cancer cohort unselected for family history of breast cancer. J Clin Oncol 33(4):304-311. doi:10. 1200/JCO.2014.57.1414

28. Cheang MCU, Martin M, Nielsen TO, Prat A, Rodriguez-Lescure A, Ruiz A, Chia SKL, Shepherd LE, Voduc D, Bernard PS, Ellis MJ, Perou CM, Di Leo A, Carey LA, on behalf of Breast International Group-North American Breast Cancer Group (2012) Quantitative hormone receptors, triple-negative breast cancer (TNBC), and molecular subtypes: a collaborative effort of the BIG-NCI NABCG. ASCO Meeting Abstracts 30(15_suppl): 1008

29. Sabatier R, Finetti P, Mamessier E, Adelaide J, Chaffanet M, Ali HR, Viens P, Caldas C, Birnbaum D, Bertucci F (2014) Prognostic and predictive value of PDL1 expression in breast cancer. Oncotarget 6(7):5449-5464

30. Wong-Brown MW, Meldrum CJ, Carpenter JE, Clarke CL, Narod SA, Jakubowska A, Rudnicka H, Lubinski J, Scott RJ 
(2015) Prevalence of BRCA1 and BRCA2 germline mutations in patients with triple-negative breast cancer. Breast Cancer Res Treat 150(1):71-80. doi:10.1007/s10549-015-3293-7

31. Walsh CS (2015) Two decades beyond BRCA1/2: homologous recombination, hereditary cancer risk and a target for ovarian cancer therapy. Gynecol Oncol 137(2):343-350. doi:10.1016/j. ygyno.2015.02.017

32. Rastelli F, Biancanelli S, Falzetta A, Martignetti A, Casi C, Bascioni R, Giustini L, Crispino S (2010) Triple-negative breast cancer: current state of the art. Tumori 96(6):875-888

33. Hiraoka N, Onozato K, Kosuge T, Hirohashi S (2006) Prevalence of FOXP3 + regulatory $\mathrm{T}$ cells increases during the progression of pancreatic ductal adenocarcinoma and its premalignant lesions. Clin Cancer Res 12(18):5423-5434. doi:10.1158/1078-0432. CCR-06-0369

34. Kobayashi N, Hiraoka N, Yamagami W, Ojima H, Kanai Y, Kosuge T, Nakajima A, Hirohashi S (2007) FOXP3+ regulatory $\mathrm{T}$ cells affect the development and progression of hepatocarcinogenesis. Clin Cancer Res 13(3):902-911. doi:10.1158/10780432.CCR-06-2363

35. Bates GJ, Fox SB, Han C, Leek RD, Garcia JF, Harris AL, Banham AH (2006) Quantification of regulatory T cells enables the identification of high-risk breast cancer patients and those at risk of late relapse. J Clin Oncol 24(34):5373-5380. doi:10.1200/ JCO.2006.05.9584

36. Galon J, Costes A, Sanchez-Cabo F, Kirilovsky A, Mlecnik B, Lagorce-Pages C, Tosolini M, Camus M, Berger A, Wind P, Zinzindohoue F, Bruneval P, Cugnenc PH, Trajanoski Z, Fridman WH, Pages F (2006) Type, density, and location of immune cells within human colorectal tumors predict clinical outcome. Science 313(5795):1960-1964. doi:10.1126/science.1129139

37. Ni YH, Ding L, Huang XF, Dong YC, Hu QG, Hou YY (2015) Microlocalization of CD68 tumor-associated macrophages in tumor stroma correlated with poor clinical outcomes in oral squamous cell carcinoma patients. Tumour Biol 36(7): 5291-5298. doi:10.1007/s13277-015-3189-5

38. Medrek C, Ponten F, Jirstrom K, Leandersson K (2012) The presence of tumor associated macrophages in tumor stroma as a prognostic marker for breast cancer patients. BMC Cancer 12:306. doi:10.1186/1471-2407-12-306

39. Naito Y, Saito K, Shiiba K, Ohuchi A, Saigenji K, Nagura H, Ohtani H (1998) CD8+ T cells infiltrated within cancer cell nests as a prognostic factor in human colorectal cancer. Cancer Res 58(16):3491-3494

40. Sato E, Olson SH, Ahn J, Bundy B, Nishikawa H, Qian F, Jungbluth AA, Frosina D, Gnjatic S, Ambrosone C, Kepner J, Odunsi T, Ritter G, Lele S, Chen YT, Ohtani H, Old LJ, Odunsi K (2005) Intraepithelial CD8 + tumor-infiltrating lymphocytes and a high $\mathrm{CD} 8+$ /regulatory $\mathrm{T}$ cell ratio are associated with favorable prognosis in ovarian cancer. Proc Natl Acad Sci USA 102(51):18538-18543. doi:10.1073/pnas.0509182102

41. Gao Q, Qiu SJ, Fan J, Zhou J, Wang XY, Xiao YS, Xu Y, Li YW, Tang ZY (2007) Intratumoral balance of regulatory and cytotoxic
$\mathrm{T}$ cells is associated with prognosis of hepatocellular carcinoma after resection. J Clin Oncol 25(18):2586-2593. doi:10.1200/ JCO.2006.09.4565

42. Mahmoud SM, Paish EC, Powe DG, Macmillan RD, Grainge MJ, Lee AH, Ellis IO, Green AR (2011) Tumor-infiltrating CD8+lymphocytes predict clinical outcome in breast cancer. J Clin Oncol 29(15):1949-1955. doi:10.1200/JCO.2010.30.5037

43. Kusuda T, Shigemasa K, Arihiro K, Fujii T, Nagai N, Ohama K (2005) Relative expression levels of Th1 and Th2 cytokine mRNA are independent prognostic factors in patients with ovarian cancer. Oncol Rep 13(6):1153-1158

44. Zhu X, Du L, Feng J, Ling Y, Xu S (2014) Clinicopathological and prognostic significance of serum cytokine levels in breast cancer. Clin Lab 60(7):1145-1151

45. Li J, Wang Z, Mao K, Guo X (2014) Clinical significance of serum $\mathrm{T}$ helper $1 / \mathrm{T}$ helper 2 cytokine shift in patients with nonsmall cell lung cancer. Oncol Lett 8(4):1682-1686. doi:10.3892/ ol.2014.2391

46. Ahmadzadeh M, Johnson LA, Heemskerk B, Wunderlich JR, Dudley ME, White DE, Rosenberg SA (2009) Tumor antigenspecific CD8 T cells infiltrating the tumor express high levels of PD-1 and are functionally impaired. Blood 114(8):1537-1544. doi:10.1182/blood-2008-12-195792

47. Francisco LM, Salinas VH, Brown KE, Vanguri VK, Freeman GJ, Kuchroo VK, Sharpe AH (2009) PD-L1 regulates the development, maintenance, and function of induced regulatory $\mathrm{T}$ cells. J Exp Med 206(13):3015-3029. doi:10.1084/jem.20090847

48. Reiss KA, Forde PM, Brahmer JR (2014) Harnessing the power of the immune system via blockade of PD-1 and PD-L1: a promising new anticancer strategy. Immunotherapy 6(4):459-475. doi:10. 2217/imt.14.9

49. Brahmer JR, Tykodi SS, Chow LQ, Hwu WJ, Topalian SL, Hwu P, Drake CG, Camacho LH, Kauh J, Odunsi K, Pitot HC, Hamid O, Bhatia S, Martins R, Eaton K, Chen S, Salay TM, Alaparthy S, Grosso JF, Korman AJ, Parker SM, Agrawal S, Goldberg SM, Pardoll DM, Gupta A, Wigginton JM (2012) Safety and activity of anti-PD-L1 antibody in patients with advanced cancer. N Engl J Med 366(26):2455-2465. doi:10.1056/NEJMoa1200694

50. Topalian SL, Hodi FS, Brahmer JR, Gettinger SN, Smith DC, McDermott DF, Powderly JD, Carvajal RD, Sosman JA, Atkins MB, Leming PD, Spigel DR, Antonia SJ, Horn L, Drake CG, Pardoll DM, Chen L, Sharfman WH, Anders RA, Taube JM, McMiller TL, Xu H, Korman AJ, Jure-Kunkel M, Agrawal S, McDonald D, Kollia GD, Gupta A, Wigginton JM, Sznol M (2012) Safety, activity, and immune correlates of anti-PD-1 antibody in cancer. N Engl J Med 366(26):2443-2454. doi:10. 1056/NEJMoa1200690

51. Powles T, Eder JP, Fine GD, Braiteh FS, Loriot Y, Cruz C, Bellmunt J, Burris HA, Petrylak DP, Teng SL, Shen X, Boyd Z, Hegde PS, Chen DS, Vogelzang NJ (2014) MPDL3280A (antiPD-L1) treatment leads to clinical activity in metastatic bladder cancer. Nature 515(7528):558-562. doi:10.1038/nature13904 